\title{
Adjuvant-Induced Liver Disease in Mice-Transfer Experiments
}

Since the introduction by FREUND and MCDERmotT ${ }^{1}$ of adjuvant containing acid-fast bacilli for the rapid immunization of animals to various tissues, it has become apparent that the adjuvant alone can cause widespread histological changes in different kinds of animals if injected i.c., i.m. or i.p. ${ }^{2}$. Repeated injections of FREUND's adjuvant thus gave rise to miliary granulomas in the liver with predominantly paravascular localization, infiltration of the periportal fields with mononuclear cells, and an increase of Kupffer cells ${ }^{2-5}$. The pathogenesis of these lesions is not clear. It could be a toxic effect of 1 or more components of the adjuvant, or it could represent an immunological effect. Adjuvant-induced arthritis can be transferred with lymphoid cell suspensions in rats", which indicates that an immunological principle is the basis of the disease. It would therefore be of interest to try to transfer the adjuvant liver disease in a similar way. Recently, ScheIfFARTH et al. ${ }^{7}$ made transfer experiments after immunization of mice with liver in FrEUND's complete adjuvant, after immunization with adjuvant alone, and after liver damage provoked by carbon tetrachloride. Successful transfer was obtained with lymphoid cells from animals immunized with liver and adjuvant, but not from animals immunized with adjuvant alone. A slight effect, however, was obtained with lymphoid cells from carbon tetrachloride-poisoned mice.

The present author has further analysed this problem with higher doses of transferred cells than those used by SCHEIFFARTH et al.

Methods. A group of $30 \mathrm{C}_{3} \mathrm{H}$ mice were injected weekly for 9 weeks with $0.1 \mathrm{ml}$ FrEUND's complete adjuvant (Difco) i.c. in the tails. Some mice died; at the end of the injection schedule only 14 were left, of which 7 were killed and their spleen cells collected and injected peritoneally into 7 recipients. Each recipient was given $350 \times 10^{6}$ cells. The remaining 7 donors got another 2 weekly injections and were then killed. Spleen cells were transferred i.p. to the same 7 recipients, each one got $250 \times 10^{6}$ cells. Thus, each recipient received in total $600 \times 10^{6}$ cells, given in 2 doses, 3 weeks apart. 2 weeks after the last transfer, the recipients were killed.

Parallel to this, a similar transfer was made from untreated mice: 19 healthy donors gave $350 \times 10^{6}$ to each of 6 mice; 1 died later. At the second transfer, only 9 mice were necessary to provide $250 \times 10^{6} /$ recipient.

The yield of spleen cells thus varied somewhat in different experimental groups, partly owing to differences in spleen size, partly to efficiency in tearing the spleens.

From each animal, 2 liver pieces were fixed and sectioned. From the healthy control donors, however, a total of only 20 livers were fixed.

The slides were coded and read blindly. From each liver piece, 4 slides were prepared. The number of granulomas in 10 microscopic fields $(\times 600)$ was counted and used as an objective score of hepatic involvement.

Results. Healthy mice (donors of control cells): among the 20 animals, the number of granuloma/20 microscopic fields ( 2 pieces were studied from each liver) varied from 13-32 with a mean of $19.7+1.1$. Standard deviation is 4.87 , and a one-tailed $t$-test at a significance level of $p=0.01$ gives an upper fiducial limit of 32.1 . Therefore, as positive findings only animals with a score over 32 are accepted. Adjuvant-treated donors: among the 14 animals that were part of this study, the score varied between 50 and 170 with a mean of $104+8.5$. All these animals are thus clearly diseased and their mean differs strongly from that of untreated animals.
Recipients given cells from adjuvant-treated donors: among these 7 animals, the score varied from $20-66$ with a mean of 33.4 $\pm \mathbf{5 . 0 . 4}$ of them showed a score above 32 .

Recipients given cells from control donors: among 5 animals, the score varied from 19-66 with a mean of $35.8+8.1$. 2 of them showed values above 32 , and a third had a value of 31

Liver involvement was thus observed after transfer of cells from both adjuvant-treated donors and control donors, and no difference between these 2 groups could be seen.

Discussion. The liver disease induced with FREUND's complete adjuvant could not be transferred either in the present experiments or in those published by ScHEIFFARTH et al. ${ }^{7}$. In contrast to the latter authors' results, significant liver involvement was registered in the present study also after transfer of normal lymphoid cells. The difference is readily explained by the differences in transferred dose of cells and also in different injection schedules. The findings of liver involvement after transfer of lymphoid cells from animals treated with carbon tetrachloride perhaps represents an augmentation of the effect seen by transfer of any lymphoid cells.

The results are thus contrary to those described by WAKSMAN and WENNERSTEN ${ }^{6}$ on adjuvant arthritis. The immediate conclusion is that the adjuvant-induced liver involvement is due to a direct toxic effect. To try to elucidate this matter further, a short series was made where the effect of FreUnD's complete and incomplete adjuvant (the latter lacking mycobacteria) was compared. In these experiments, a scoring of liver involvement with only $0,+$ and ++ was made. The following results were obtained: 5 mice immunized with liver + complete adjuvant: $2+, 3++.5$ mice injected with complete adjuvant alone: $3+, 2++.5$ mice injected with incomplete adjuvant alone: all scored 0 .

Thus it was not possible to demonstrate a definite toxic effect of the non-bacterial components of the FREUND's adjuvant, in contrast to what other authors ${ }^{2,4}$ have claimed.

Zusammenfassung. Milzzellen von $\mathrm{C}_{3} \mathrm{H}$-Mäusen mit adjuvant induzierter Leberkrankheit hatten bei gesunden Mäusen keine stärkere toxische Wirkung als solche von normalen Mäusen.

\section{A. LunDouist}

Tornblad Institute and Department of Internal Medicine, Lund (Sweden), 2 July 1968.

1 J. Freund and K. McDermott, Proc. Soc. exp. Biol. Mcd. 49 , $548(1942)$.

2 J. W. Steiner, B. Langer and D. L. Schatz, Archs Path. 70, $424(1960)$.

s R. J. JAmel and D. Koffler, Br. J. exp. Path, 42, 338 (1961)

4 A. LAuger, C. TaL and A. J. BeHAR, Br. J. exp. Path. 40, 1 (1959).

5 K. H. Soergel and K. H. Fridel, J. lab. clin. Med. 04, 51 (1964).

- B. H. Waksman and C. Wennersten, Int. Archs Allergy appl. Irumun. 23, 129 (1963).

7 F. Scheiffarth, H. WARnatz and K. MAYer, J. Immun. 98, $396(1967)$. 